\title{
Implikasi Pelayanan Terhadap Kepuasan Pelanggan Pada PT Kayndra Dwi Pesona Tangerang
}

\author{
Dirgahayu Erri' ${ }^{1}$, Viera Septia Nur ${ }^{2}$ \\ ${ }^{1,2}$ Universitas Bina Sarana Informatika \\ Jl. Kramat Raya No 98, Senen, Jakarta Pusat, Indonesia \\ e-mail: ${ }^{1}$ dirgahayu.dge@bsi.ac.id, ${ }^{2}$ septianurviera12@gmail.com
}

\begin{abstract}
Informasi Artikel Diterima: 16-02-2021 Direvisi: 23-03-2021 Disetujui: 18-04-2021
Abstrak

Pelayanan merupakan sebuah aktivitas bagi penyedia jasa yang harus dikerjakan dengan baik oleh perusahaan. Banyak strategi yang dapat dilakukan untuk meningkatkan kepuasan pelanggan, kaitannya dengan kualitas pelayanan, dimana aspek tersebut sangat penting untuk mencapai kepuasan pelanggan. Tujuan penelitian ini adalah untuk mengetahui ada tidaknya pengaruh pelayanan terhadap kepuasan pelanggan, seberapa besar kontribusi pelayanan terhadap kepuasan pelanggan dan mengetahui koefisien regresi pelayanan terhadap kepuasan pelanggan pada PT Kayndra Dwi Pesona Tangerang. Penelitian ini menggunakan tehnik sampling jenuh dengan responden berjumlah 30 pelanggan. Hasil penelitian ini menggunakan uji korelasi dimana nilai koefisien korelasi mendekati 1 berarti memiliki hubungan yang kuat antara pelayanan terhadap kepuasan pelanggan. Sedangkan hasil koefisien determinasi dari hasil pengaruh pelayanan terhadap kepuasan pelanggan menggambarkan besarnya kontribusi variabel yang diteliti. Penelitian ini juga mencari koefisien regresi diperoleh dalam bentuk persamaan yang didapatkan dari perhitungan statistik.
\end{abstract}

Kata Kunci: Pelayanan, Kepuasan Pelanggan.

\begin{abstract}
Service is an activity for service providers that the company must do well. Many strategies can be done to increase customer satisfaction, about service quality, where this aspect is very important to achieve customer satisfaction. The purpose of this study is to determine whether there is an effect of service on customer satisfaction, how much service contribution to customer satisfaction and to know the service regression coefficient on customer satisfaction at PT Kayndra Dwi Pesona Tangerang. This study used a saturated sampling technique with 30 respondents. The results of this study use a correlation test where the correlation coefficient value is close to 1 which means that it has a strong relationship between service and customer satisfaction. While the coefficient of determination from the effect of service on customer satisfaction illustrates the magnitude of the contribution of the variables studied. This research is also looking for regression coefficients obtained in the form of equations obtained from statistical calculations.
\end{abstract}

Keywords: Customer Service, Satisfaction.

\section{Pendahuluan}

Pelayanan merupakan sebuah kata bagi penyedia jasa yang harus dikerjakan dengan baik oleh perusahaan, oleh sebab itu suatu perusahaan harus memiliki strategi khusus untuk mengelola bisnis jasa dengan baik. Strategi khusus yang dimaksud mengenai tentang hal-hal yang dapat mempengaruhi kepuasan pelanggan. Kualitas pelayanan merupakan aspek terpenting untuk mencapai kepuasan pelanggan, karena untuk memahami harapan dari pelanggan yaitu keamanan, kecepatan, ketepatan waktu, kemudahan dan tanggung jawab perusahaan.

Mempertahankan kepuasan pelanggan berarti juga menjaga kelangsungan hidup perusahaan. Meningkatkan jumlah pelanggan dalam bisnis adalah kewajiban, maka untuk meningkatkan pelanggan perusahaan harus mampu memberikan kepuasan kepada pelanggan (Kusuma, 2018). Misalnya, memberikan pelayanan yang mutunya lebih baik, ramah, murah senyum, sopan dan fasilitas yang memadai. Pelayanan yang diberikan secara optimal akan mampu memberikan kepuasan lebih bagi pelanggan, mereka akan merasa diperhatikan dan dipenuhi semua harapannya jika diberikan pelayanan yang terbaik, sehingga akan tercipta hubungan baik antara pelanggan dan perusahaan tersebut.

Menurut Windasuri dalam (Nugroho, 2018) mendefinisikan bahwa Pelayanan merupakan tanggung jawab setiap orang, sebab setiap orang berperan dalam proses pelayanan, memiliki andil memberikan hasil kerja terbaik demi mendukung 
hasil akhir terbaik yang diberikan kepada pelanggan. Gronroos dalam (Ratminto \& Atik, 2015) menyebut Pelayanan adalah suatu aktivitas atau serangkaian aktivitas yang bersifat tidak kasat mata (tidak dapat diraba) yang terjadi sebagai akibat adanya interaksi antara konsumen dengan karwayan atau hal-hal lain yang disediakan oleh perusahaan pemberi pelayanan yang dimaksudkan untuk memecahkan permasalahan konsumen/pelanggan. Menurut (Erri, 2017) Pelayanan merupakan salah satu bentuk kegiatan/aktifitas yang diberikan oleh satu pihak atau lebih kepada pihak lain yang memiliki hubungan dengan tujuan untuk dapat memberikan kepuasan kepada pihak kedua yang bersangkutan atas barang dan jasa yang diberikan.

Pelayanan prima saat ini menjadi salah satu faktor yang diutamakan oleh banyak perusahaan karena memiliki banyak manfaat yang berguna bagi perusahaan. Berikut ini lima manfaat pelayanan menurut Frimayasa dalam (Nugroho, 2018) yaitu: meningkatkan hubungan klien dan pelayanan publik, memproduksikan inovasi dan kreatifitas dalam memberikan pelayanan, menghargai karyawan yang memberikan pelayanan prima, tingkat kepercayaan dalam pelayanan publik lebih tinggi, pelayanan prima yang diberikan dapat selalu dikenang.

Layaknya mata uang, perilaku pelayanan pelanggan menjadi hal berharga yang ditukarkan dalam transaksi internal maupun eksternal perusahaan. Seperti umumnya mata uang, layanan pelanggan memiliki dua sisi, atau sering disebut dengan dimensi layanan yang meliputi dimensi prosedural dan dimensi personal. Standar pelayanan merupakan ukuran yang dibakukan dalam penyelenggara pelayanan publik yang wajib ditaati oleh pemberi atau penerima pelayanan, diantaranya meliputi prosedur pelayanan, waktu penyelesaian, biaya pelayanan, produk pelayanan, sarana dan prasarana, kompetensi petugas pembeli layanan. (Atmaja, 2018)

Pelayanan yang baik memiliki ciri-ciri tersendiri dan hampir semua perusahaan menggunakan kriteria yang sama untuk mengatakan ciri-ciri pelayanan yang baik. Secara umum pelayanan yang baik adalah pelayanan yang mampu memberikan kepuasan kepada pelanggannya secara terus-menerus. Beberapa ciri pelayanan yang baik yang harus diikuti oleh manajemen dalam melayani pelanggan atau nasabah yaitu: tersedia karyawan yang baik, sarana dan prasarana yang baik, bertanggung jawab dari awal hingga selesai, melayani dengan cepat dan tepat, kemampuan berkomunikasi, menjamin kerahasiaan setiap transaksi, memiliki pengetahuan dan kemampuan yang baik, memahami kebutuhan pelanggan, memberikan kepercayaan kepada pelanggan. (Rosita, 2018)

Kepuasan pelanggan merupakan salah satu faktor yang menentukan loyalitas pelanggan terhadap suatu perusahaan, dengan kata lain kepuasan pelanggan menentukan eksistensi suatu perusahaan dalan menjalankan bisnisnya. Menurut Kotler et al dalam (Gunawan, 2017) Kepuasan pelanggan merupakan tingkat kepuasan seseorang setelah membandingkan kinerja (atau hasil) yang ia rasakan dibandingkan dengan harapannya. Menurut Tjiptono \& Chandra dalam (Kurniasari, 2019) yaitu "kata kepuasan (satisfaction) berasal dari kata latin "satis" (artinya cukup baik, memadai) dan "facio" (melakukan atau membuat). Kepuasan bisa diartikan sebagai "upaya pemenuhan sesuatu" atau "membuat sesuatu memadai".

Menurut Kasmir dalam (Rosita, 2018) seringkali tanpa disadari jumlah pelanggan terus meningkat, baik jumlah maupun kualitasnya dari waktu ke waktu. Hal ini disebabkan karyawan dan pimpinan terus berusaha mempertahankan pelayanan terbaiknya dan berusaha untuk mempebaiki setiap kekurangan dan kesalahan. Perbaikan terus dilakukan sesuai dengan berbagai kondisi perkembangan yang terjadi misalnya perkembangan, persaingan, teknologi, lingkungan masyarakat dan perilaku pelanggan. Keuntungan kepuasan pelanggan yang diberikan oleh karyawan akan berimbas sangat luas bagi peningkatan keuntungan perusahaan. Adapun keuntungan bagi perusahaan dan karyawan atas kepuasan pelanggan yaitu: loyalitas pelanggan, mengulang kembali pembelian produk, menambah pembelian, memberikan promosi gratis dari mulut, keuntungan laba.

Faktor-faktor yang mempengaruhi kepuasan pelanggan yang disampaikan oleh Kuswandi dalam (Irawan, R., 2019) yang terdiri dari: produk atau jasa yang bermutu, pelayanan yang memenuhi harapan pelanggan, penawaran harga yang lebih murah, waktu penyerahan tepat waktu, jaminan keamanan yang tidak membahayakan pelanggan. Pada umumnya harapan pelanggan merupakan perkiraan atau keyakinan pelanggan tentang apa yang akan diterimanya apabila membeli atau mengkonsumsi suatu produk baik barang ataupun jasa, sedangkan kinerja atau hasil yang dirasakan merupakan persepsi pelanggan terhadap apa yang ia terima setelah mengkonsumsi produk yang ia beli. (Riyanto, 2018) PT Kayndra Dwi Pesona sebagai tempat penelitian adalah sebuah perusahaan yang bergerak dibidang Agent Tours and Travel serta menyelenggarakan kegiatan layanan untuk pembelian tiket, baik transportasi darat, laut dan udara. PT Kayndra Dwi Pesona menyediakan jasa untuk pemandu wisata (Tour Guide) dan juga jasa travel atau jasa transportasi dalam bentuk bus atau mobil. Pelayanan mengantarkan para pelanggannya pergi sampai ke tujuan mereka merupakan kewajiban, sehingga dalam menjalankan aktivitas organisasinya perusahaan mengutamakan pelayanan terbaik terhadap pelanggan.

\section{Metode Penelitian}

Peneliti menggunakan pendekatan kuantitatif 
untuk mengolah data-data yang diperoleh dari lokasi penelitian, data yang berbentuk angka atau data kuantitatif yang diangkat. Penelitian menggunakan beberapa metode pengumpulan data, yaitu:

1. Metode Observasi

Dengan metode ini peneliti melakukan pengumpulan data secara langsung dengan melihat objek yang diteliti sesuai dengan topik yang dibahas khususnya di PT Kayndra Dwi Pesona Tangerang.

2. Metode Wawancara

Merupakan metode dengan cara mengajukan pertanyaan kepada bapak Gerry Lainil Fauzi selaku Supervisor PT Kayndra Dwi Pesona untuk mencari informasi mendalam tentang obyek yang akan diteliti.

3. Metode Kuesioner

Dengan metode ini peneliti melakukan pembagian lembar pernyataan kepada responden yang bersangkutan untuk mendapatkan informasi tentang masalah yang dibahas dalam penelitian.

4. Studi Dokumentasi

Dengan metode ini peneliti memperoleh data dengan cara membaca dan mempelajari bukubuku literatur dan jurnal sebagai referensi pendukung untuk memperkuat obyektifitas penelitian.

Kisi-kisi operasional mencangkup dimensi dan indikator dari dua variabel yang digunakan dalam penelitian ini yaitu variabel Pelayanan (X) dan variabel Kepuasan Pelanggan (Y), kemudian dikembangkan menjadi pernyataan-pernyataan untuk dijadikan sebagai bahan kuesioner sebagai berikut:

Dimensi variabel Pelayanan (Variabel X) yang dikutip dari buku Rusyadi dalam (Safitri, 2018) mengungkapkan ada sepuluh (10) dimensi kualitas pelayanan yang terdiri dari bukti fisik, keandalan, kesigapan, kompetensi, kesopanan, kredibilitas, keamanan, akses, komunikasi, dan memahami. Variabel Kepuasan Pelanggan (Variabel Y) dikutip dari buku Majid dalam (Safitri, 2018) bahwa faktor yang sering digunakan dalam mengevaluasi kepuasan pelanggan terhadap suatu produk meliputi tepat waktu (On Time Perfomance), Aksebilitas (Accessbility), Pelayanan (Service), Harga (Price).

Uji instrumen penelitian mencakup berbagai cara untuk menentukan uji validitas dan uji reabilitas, peneliti menggunakan aplikasi IBM SPSS Statistic versi 21 untuk menguji validitas dan menguji reabilitas. Menurut Arikunto dalam (Safitri, 2018) validitas adalah suatu ukuran yang menunjukkan tingkat-tingkat kevalidan atau kesahihan sesuatu instrumen. Suatu instrumen yang valid atau sahih mempunyai validitas tinggi. Sebaliknya, instrumen yang kurang valid berarti memiliki validitas rendah. Sebuah instrumen dikatakan valid apabila mampu mengukur apa yang diinginkan. Sebuah instrumen dikatakan valid apabila dapat mengungkap data dari variabel yang diteliti secara tepat.

Menurut Arikunto dalam (Safitri, 2018) reliabilitas menunjuk pada satu pengertian bahwa sesuatu instrumen cukup dapat dipercaya untuk digunakan sebagai alat pengumpul data karena instrumen tersebut sudah baik. Menurut Sekaran dalam (Safitri, 2018) reliabilitas kurang dari 0,6 adalah kurang baik, sedangkan 0,7 dapat diterima dan diatas 0,8 adalah baik.

Konsep dasar perhitungan yang digunakan dalam penelitian ini adalah:

1. Populasi dan Sampel

Menurut (Sugiyono, 2016) populasi adalah wilayah generalisasi yang terdiri atas, obyek/subyek yang mempunyai kualitas dan karakteristik tertentu yang ditetapkan peneliti untuk dipelajari kemudian ditarik kesimpulannya. Dalam penelitian ini peneliti menggunakan teknik sampling jenuh. Jumlah sampel ditentukan dengan menggunakan rumus Slovin. Menurut Suharsaputra dalam (Kusuma Rani Dwi, 2018), terkait dengan besar sampel yang akan diambil Slovin mengemukakan formula untuk penentuan besarnya sampel, sebagai berikut:

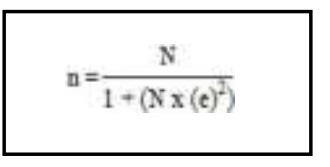

2. Skala Likert

Menurut (Sugiyono, 2016) Skala Likert digunakan untuk mengukur sikap, pendapat, dan persepsi seseorang atau sekelompok orang tentang fenomena sosial. Dalam penelitian, fenomena sosial ini telah ditetapkan secara spesifik oleh peneliti, yang selanjutnya disebut sebagai variabel penelitian. Dengan Skala Likert, maka variabel yang akan diukur dijabarkan menjadi indikator variabel. Kemudian indikator tersebut dijadikan sebagai titik tolak untuk menyusun item-item instrumen yang dapat berupa pernyataan atau pertanyaan. Untuk keperluan analisis kuantitatif, maka jawaban itu dapat diberi skor.

3. Uji Koefisien Korelasi

Menurut Arikunto dalam (Safitri, 2018) koefisien korelasi adalah suatu alat statistik, yang dapat digunakan untuk membandingkan hasil pengukuran dua variabel yang berbeda agar dapat menentukan tingkat hubungan antara variabel. Diukur dengan suatu nilai yang disebut koefisien korelasi dan diberi simbol r. Korelasi yang digunakan adalah Korelasi Bivariate menurut buku SPSS Korelasi Bivariate adalah korelasi pearson, digunakan untuk mengukur keeratan hubungan di antara hasil pengamatan dari populasi yang memiliki dua variansi. Angka korelasi berkisar pada 0 (tak ada korelasi sama sekali) sampai 1 (korelasi sempurna). Angka korelasi di atas 0,5 menunjukan korelasi yang cukup kuat sedangkan di bawah 0,5 korelasi cukup lemah. Selain itu, tanda korelasi negatif menunjukan arah yang berlawanan, sedangkan tanda positif menunjukan arah yang sama.

4. Uji Koefisien Determinasi 
Menurut (Sugiyono, 2016) untuk mencari pengaruh varian variabel dapat digunakan teknik statistik dengan menghitung besarnya koefisien determinasi. Koefisien determinasi dihitung dengan mengkuadratkan koefisien korelasi yang telah ditemukan, dan selanjutnya dikalikan dengan $100 \%$ sehingga $\left(r^{2}\right) \times 100 \%$.

5. Uji Persamaan Regresi

Menurut (Sugiyono, 2016) persamaan regresi dapat digunakan untuk melakukan prediksi seberapa tinggi nilai variabel dependent bila nilai variabel independent dimanipulasi (dirubahubah). Persamaan regresi membentuk $\mathrm{Y}=\mathrm{a}+\mathrm{Bx}$.

\section{Hasil dan Pembahasan}

PT Kayndra Dwi Pesona Tangerang didirikan pada 3 November 2004, adalah sebuah Biro Perjalanan Wisata yang memiliki manajemen organisasi dan tumbuh dengan baik. Sebagai salah satu tour operator yang sudah hampir 10 tahun terakhir ini memiliki divisi yang tidak saja secara khusus menyediakan fasilitas perjalanan, namun sekaligus juga melayani secara eksklusif setiap keperluan perjalanan pejabatpejabat dari instansi, lembaga dan badan-badan pemerintah termasuk para anggota Dewan Perwakilan Rakyat Daerah di wilayah provinsi Banten, tentunya PT Kayndra Dwi Pesona Tangerang sudah memiliki cukup pengalaman berinteraksi dengan sistem yang berlaku, dan karenanya dapat menjadi mitra yang patut diandalkan untuk memberikan layanan maksimal kepada semua pihak yang berkepentingan.

Populasi atau objek yang dijadikan penelitian ini adalah pelanggan pada PT Kayndra Dwi Pesona Tangerang dengan karakteristik sebagai berikut:

1. Karakteristik Berdasarkan Jenis Kelamin

Tabel 1. Karakteristik Berdasarkan Jenis Kelamin

\begin{tabular}{cccc}
\hline No & Jenis Kelamin & Jumlah & Persentase \\
\hline 1 & Perempuan & 14 & $47 \%$ \\
2 & Laki-Laki & 16 & $53 \%$ \\
\hline & Total & $\mathbf{3 0}$ & $\mathbf{1 0 0 \%}$ \\
\hline
\end{tabular}

Sumber: Data diolah (2020) menggunakan SPSS versi 21

Berdasarkan tabel 1 dapat diketahui bahwa responden Perempuan memiliki persentase $47 \%$ dengan jumlah 14 orang dan responden Laki-Laki memiliki persentase 53\% dengan jumlah 16 orang.

2. Berdasarkan Usia

Tabel 2. Karaktetristik Berdasarkan Usia

\begin{tabular}{cccc}
\hline No & Usia & Jumlah & Persentase \\
\hline $\mathbf{1}$ & $20-25$ & 9 & $30 \%$ \\
$\mathbf{2}$ & $26-30$ & 6 & $20 \%$ \\
$\mathbf{3}$ & $31-40$ & 11 & $37 \%$ \\
$\mathbf{4}$ & $41-45$ & 4 & $13 \%$ \\
\hline & Total & $\mathbf{3 0}$ & $\mathbf{1 0 0 \%}$ \\
\hline
\end{tabular}

Sumber: Data diolah (2020) menggunakan SPSS versi 21

Berdasarkan Tabel 2 dapat dijelaskan bahwa responden yang berusia 20-25 memiliki persentase sebesar 30\% dengan jumlah 9 responden, usia 26-30 memiliki persentase sebesar $20 \%$ dengan jumlah 6 responden, usia 31-40 memiliki persentase sebesar $37 \%$ dengan jumlah 11 responden, usia 41-45 memiliki persentase sebesar 13\% dengan jumlah 4 responden.

3. Berdasarkan Pendidikan

Tabel 3. Karakteristik Berdasarkan Pendidikan

\begin{tabular}{cccc}
\hline No & Kategori & Jumlah & Persentase \\
\hline 1 & SMA/Sederajat & 4 & $13 \%$ \\
2 & Diploma & 10 & $33 \%$ \\
3 & Sarjana & 16 & $53 \%$ \\
\hline & Total & $\mathbf{3 0}$ & $\mathbf{1 0 0 \%}$ \\
\hline
\end{tabular}

Sumber: Data diolah (2020) menggunakan SPSS versi 21

Berdasarkan Tabel 3 dapat dijelaskan bahwa responden dengan tingkat Pendidikan SMA/Sederajat memiliki persentase sebesar $13 \%$ dengan jumlah 4 responden, Diploma memiliki persentase sebesar 33\% dengan jumlah 10 responden, Sarjana memiliki persentase sebesar 53\% dengan jumlah 16 responden.

Uji instrumen dilakukan terhadap indikator dari masing-masing variabel agar dapat diketahui tingkat kevalidan dan keandalan indikator sebagai alat ukur variabel. Berikut hasil dari Uji Validitas dan Uji Realibitas pada Variabel Pelayanan terhadap Kepuasan Pelanggan dalam melakukan Uji Validitas dan Uji reliabitas menggunakan SPSS 21, sebagai berikut:

Tabel 4. Hasil Uji Validitas Pelayanan

\begin{tabular}{ccccc}
\hline Variabel & \multicolumn{1}{c}{ Indikator } & r Hitung & r Tabel & Keterangan \\
\hline \multirow{6}{*}{} & X1 & 0,904 & 0,361 & Valid \\
& X2 & 0,445 & 0,361 & Valid \\
& X3 & 0,707 & 0,361 & Valid \\
& X4 & 0,693 & 0,361 & Valid \\
& X5 & 0,481 & 0,361 & Valid \\
Pelayanan & X6 & 0,523 & 0,361 & Valid \\
(X) & X7 & 0,578 & 0,361 & Valid \\
& X8 & 0,617 & 0,361 & Valid \\
& X9 & 0,482 & 0,361 & Valid \\
& X10 & 0,458 & 0,361 & Valid \\
\hline
\end{tabular}

Sumber: Data diolah (2020) menggunakan SPSS 21

Tabel 5. Hasil Uji Validitas Kepuasan Pelanggan

\begin{tabular}{ccccc}
\hline Variabel & \multicolumn{2}{l}{ Indikator $\mathbf{r}$ Hitung } & $\mathbf{r}$ Tabel & Keterangan \\
\hline \multirow{6}{*}{} & Y1 & 0,800 & 0,361 & Valid \\
& Y2 & 0,577 & 0,361 & Valid \\
& Y3 & 0,391 & 0,361 & Valid \\
& Y4 & 0,476 & 0,361 & Valid \\
Kepuasan & Y5 & 0,705 & 0,361 & Valid \\
Pelanggan & Y6 & 0,481 & 0,361 & Valid \\
(Y) & Y8 & 0,738 & 0,361 & Valid \\
& Y9 & 0,772 & 0,361 & Valid \\
& Y10 & 0,589 & 0,361 & Valid \\
\hline Sumber: & 0,361 & Valid \\
\hline
\end{tabular}

Sumber: Data diolah (2020) menggunakan SPSS 21

Hasil perhitungan Uji Validitas Variabel X dan Y menggunakan SPSS 21 dengan membandingkan nilai person correlation (korelasi product moment), maka $\mathrm{r}$ hitung $>\mathrm{r}$ tabel dengan nilai $\mathrm{r}$ tabel sebesar 0,361 dan taraf signifikan kesalahan 5\%, dapat di 
simpulkan bahwa variabel Pelayanan $(\mathrm{X})$ dan variabel Kepuasan Pelanggan (Y) yaitu valid.

Reliabilitas suatu kuesioner dari perhitungan menggunakan SPSS 21 dapat dilihat dari nilai Croncbach's Alpha kemudian diinterpretasikan pada tabel 6 berikut ini:

Tabel 6. Hasil Uji Reliabilitas

\begin{tabular}{cccc}
\hline No & Variabel & Croanbach's Alpha & Keterangan \\
\hline 1 & Pelayanan (X) & 0,795 & Reliabel \\
2 & $\begin{array}{c}\text { Kepuasan } \\
\text { Pelanggan (Y) }\end{array}$ & 0,807 & Sangat Reliabel \\
\hline
\end{tabular}

Sumber: Data diolah (2020) menggunakan SPSS 21

Hasil dari uji reliabilitas variabel X (Pelayanan) sebesar 0,795 dengan rentang nilai pada Alpha Croanbach's diantara $(0,61-0,80)$ dinyatakan reliabel. Sedangkan variabel Y (Kepuasan Pelanggan) sebesar 0,807. Rentang nilai pada Alpha Croanbach's diantara (0,81-1,00) dinyatakan sangat reliabel.

\section{Uji Koefisien Korelasi}

Untuk mengetahui seberapa kuat hubungan variabel X Pelayanan terhadap variabel Y Kepuasan Pelanggan, maka peneliti menggunakan perhitungan Koefisien Korelasi menggunakan SPSS versi 21, sebagai berikut:

Tabel 7. Hasil Uji Koefisien Korelasi Correlations

\begin{tabular}{llcc}
\hline & & Pelayanan & $\begin{array}{c}\text { Kepuasan } \\
\text { Pelanggan }\end{array}$ \\
\hline $\begin{array}{llc}\text { Pelayanan } \\
(\mathrm{X})\end{array}$ & $\begin{array}{l}\text { Pearson } \\
\text { Correlation }\end{array}$ & 1 & $.623^{* *}$ \\
& Sig. (2-tailed) & &, 000 \\
& $\mathrm{~N}$ & 30 & 30 \\
Kepuasan & Pearson & $.623^{* *}$ & 1 \\
Pelanggan & Correlation & & \\
(Y) & Sig. (2-tailed) &, 000 & 30 \\
& $\mathrm{~N}$ & 30 & \\
\hline
\end{tabular}

**. Correlation is significant at the 0.01 level (2-tailed). Sumber: Data diolah (2020) menggunakan SPSS 21

Berdasarkan tabel 7, dari hasil uji koefisien korelasi dapat diketahui bahwa nilai $\mathrm{r}$ sebesar 0,623 dapat diartikan bahwa hubungan antara Pelayanan (X) dan Kepuasan Pelanggan (Y) pada PT Kayndra Dwi Pesona Tangerang memiliki hubungan yang kuat sesuai tabel korelasi.

\section{Uji Koefisien Determinasi}

Setelah melakukan perhitungan uji koefisien korelasi, selanjutnya adalah mencari hasil uji koefisien determinasi. Uji koefisien determinasi digunakan untuk mengetahui seberapa besar kemampuan variabel Independen (Pelayanan) dan variabel Dependen (Kepuasan Pelanggan) yang dilihat melalui $R$ square.
Berdasarkan perhitungan Koefisien Determinasi menggunakan SPSS versi 21 sebagai berikut:

Tabel 8. Model Summary

\begin{tabular}{ccccc}
\hline Model & R & R Square & $\begin{array}{c}\text { Adjusted } \\
\text { R Square }\end{array}$ & $\begin{array}{c}\text { Std. Error of } \\
\text { the Estimate }\end{array}$ \\
\hline 1 & $.623^{\mathrm{a}}$ &, 389 &, 367 & 2,42554
\end{tabular}

a. Predictors : (Constant), (Pelayanan)

Sumber: Data diolah (2020) menggunakan SPSS 21

Berdasarkan perhitungan menggunakan SPSS versi 21 tabel 8 dapat diketahui bahwa nilai R Square sebesar 0,389 artinya persentase pengaruh pelayanan terhadap kepuasan pelanggan sebesar 38,9\%. Sedangkan sisanya $61,1 \%$ dipengaruhi oleh faktorfaktor lain yang tidak diteliti oleh peneliti dalam penelitian ini. Hal ini dapat menjadi pengembangan dalam penelitian berikut kedepannya.

\section{Uji Persamaan Regresi}

Uji persamaan regresi digunakan untuk memprediksi seberapa jauh perubahan nilai kepuasan pelanggan apabila nilai pelayanan diubah, maka digunakan uji persamaan regresi. Berdasarkan hasil analisis perhitungan menggunakan SPSS versi 21 sebagai berikut:

Tabel 9. Hasil Uji Persamaan Regresi Coefficients $^{\mathrm{a}}$

\begin{tabular}{|c|c|c|c|c|c|}
\hline \multirow{2}{*}{ Model } & \multicolumn{2}{|c|}{$\begin{array}{l}\text { Unstandardized } \\
\text { Coefficients }\end{array}$} & \multirow{2}{*}{$\begin{array}{c}\begin{array}{c}\text { Standardized } \\
\text { Coefficients }\end{array} \\
\text { Beta }\end{array}$} & \multirow{2}{*}{$\mathrm{t}$} & \multirow{2}{*}{ Sig. } \\
\hline & B & $\begin{array}{l}\text { Std. } \\
\text { Error }\end{array}$ & & & \\
\hline \multirow[t]{2}{*}{1} & $\begin{array}{l}\text { (Con 15,088 } \\
\text { stant) }\end{array}$ & 6,662 & & 2,265 & 031 \\
\hline & $\begin{array}{c}\text { Pelay } \\
\text { anan }\end{array}$ & ,152 & 623 & 4,219 &, 000 \\
\hline
\end{tabular}

a. Dependent Variable: Kepuasan Pelanggan

Sumber: Data diolah (2020) menggunakan SPSS versi 21

Berdasarkan perhitungan menggunakan SPSS versi 21 pada tabel 9 persamaan regresi linier, yaitu:

$$
\mathrm{Y}=\mathrm{a}+\mathrm{bx} \text { atau } \mathrm{Y}=15,088+0,642 \mathrm{X}
$$

Persamaan tersebut menunjukkan bahwa Nilai Konstanta (a) sebesar 15,088 artinya, jika $\mathrm{X}=0$ atau tanpa adanya pelayanan maka kepuasan pelanggan sebesar 15,088, sedangkan untuk koefisien regresi (b) sebesar 0,642 artinya jika X naik 1 angka maka nilai kepuasan pelanggan akan naik sebesar 0,642

\section{Kesimpulan}

Berdasarkan penelitian mengenai pelayanan berimplikasi terhadap kepuasan pelanggan pada PT Kayndra Dwi Pesona Tangerang, maka peneliti dapat menarik kesimpulan sebagai berikut: 
1. Berdasarkan hasil perhitungan uji koefisien korelasi menggunakan SPSS versi 21 di peroleh hasil sebesar $r=0,623$ yang menunjukan bahwa adanya hubungan yang kuat, hal ini berarti pelayanan berimplikasi terhadap kepuasan pelanggan pada PT Kayndra Dwi Pesona Tangerang.

2. Berdasarkam hasil perhitungan uji koefisien determinasi menggunakan SPSS versi 21 diperoleh hasil R Square sebesar 38,9\% yang menunjukan bahwa variabel pelayanan berimplikasi terhadap kepuasan pelanggan dan sisanya sebesar $61,1 \%$ yang dipengaruhi oleh faktor lain yang belum diteliti dan ini dapat menjadi pengembangan penelitian kedepannya.

3. Berdasarkan perhitungan Persamaan Regresi diperoleh $\mathrm{Y}=15,088+0,642 \mathrm{X}$ ini menunjukan bahwa jika nilai pelayanan 0 maka kepuasan pelanggan adalah 15,088 atau dengan kata lain variabel kepuasan pelanggan sudah ada sebesar 15,088 tanpa dipengaruhi oleh variabel pelayanan dan jika pelayanan (X) naik atau turun 1 angka akan menaikan atau menurunkan kepuasan pelanggan dengan nilai sebesar 0,642.

\section{Referensi}

Atmaja, J. (2018). Kualitas pelayanan dan kepuasan nasabah terhadap loyalitas pada bank BJB Ecodomica, 2(1), 49-63.

Erri, D. \& A. (2017). Pengaruh Kualitas Pelayanan Kesehatan Terhadap Kepuasan Pasien Peserta BPJS Pada RS Hermina Daan Mogot Jakarta. Simnasiptek 2017 BSI, 48-55. http://seminar.bsi.ac.id/simnasiptek/index.php/ simnasiptek-2017/article/view/156

Gunawan, C. (2017). Customer Value dan Strategi Kepuasan Pelanggan Bisnis Restoran Cepat Saji. CV Budi Utama.
Irawan, R., et all. (2019). Pengaruh Kualitas Pelayanan Terhadap Kepuasan Pelanggan di PT Lintas Timur Sejahtera Jakarta Utara. Akrab Juara, 4(2), 198-215.

Kurniasari, R. (2019). Pengaruh Kualitas Pelayanan Terhadap Peningkatan Kepuasan Pelanggan Pada Hotel Bogor. Widya Cipta, 3(1), 129-133.

Kusuma, R. D. (2018). Pengaruh Pelayanan Prima Terhadap Kepuasan Peserta Diklat Pada Balai Diklat Industri (BDI) Jakarta. In Repository Bina Sarana Informatika: Vol. (Issue). https://repository.bsi.ac.id/index.php/repo/vie witem $/ 17120$

Nugroho, D. (2018). Pengaruh Pelayanan Terhadap Kepuasan Pelanggan Pada Koperasi Serba Usaha Zam Zam Depok. Repository BSI, =(=), 7-26.

Ratminto \& Atik. (2015). Manajemen Pelayanan. Pustaka Pelajar.

Riyanto, A. (2018). Implikasi Kualitas Pelayanan Dalam Meningkatkan Kepuasan Pelanggan Pada PDAM Cibadak Sukabumi. Ecodemica, 2(1), 117-124.

Rosita, M. (2018). Pengaruh Kualitas Pelayanan Terhadap Kepuasan Pelanggan Pada Rabbani Clothing Store Cabang Depok. https://repository.bsi.ac.id/index.php/repo/vie witem $/ 17098$

Safitri, F. (2018). Pengaruh Pelayanan Terhadap Kepuasan Pelanggan Pada Unit Pengelola Anjungan Dan Graha Wisata TMII Jakarta. https://repository.bsi.ac.id/index.php/repo/vie witem $/ 16023$

Sugiyono. (2016). Metode Penelitian Kuantitatif, Kualitatif, $R \& D$. Alfabeta. 